\title{
Bonding of Plywood Using Hot Melt Adhesives
}

Milan Brožek ${ }^{1}$, Alexandra Nováková1, Helena Píšová1,2

${ }^{1}$ Department of Material Science and Manufacturing Technology, Faculty of Engineering, Czech University of Life Sciences Prague. Kamýcká 129, 16521 Praha 6 - Suchdol, Czech Republic. E-mail: brozek@tf.czu.cz

${ }^{2}$ Master's degree Student

The paper presents the strength tests results of joints made by use of two hot melt adhesives. The tests were carried out according to the modified standard ČSN EN 1465 (66 8510) and ČSN EN 205 (66 8508). For bonding the threelayer plywood of $4 \mathrm{~mm}$ thickness was used. The test samples of $100 \times 25 \mathrm{~mm}$ size were cut out from a semi-product in the direction of its longer side, in the oblique direction and in the direction of its shorter side. The specimen pairs were bonded using the hot melt glue gun. All assemblies were loaded up to their destruction. The destructive force and the destruction type were registered. From the results of carried out tests evaluation it follows that hot melt adhesives can be recommended for bonding plywood. The bonding strength of bonded joint is comparable to the strength of the bonded material. Finally the technical-economical evaluation of the experiments was carried out.

Keywords: three-layer plywood; adhesive bonding; hot melt adhesive; hot melt glue gun; bonded joints testing

\section{References}

[1] BROŽEK, M. (2013). Technical-economical evaluation of plywood bonding. In.: Trends in Agricultural Engineering. Prague, Czech University of Life Sciences Prague, 100-105.

[2] BROŽEK, M. (2014). Technical-economical evaluation of beech plywood bonding. In.: Engineering for Rural Development. Jelgava, Latvia University of Agriculture, 168-173.

[3] BROŽEK, M. (2015). Spruce plywood bonding. Manufacturing Technology. 15, 3, 285-291.

[4] BROŽEK, M. (2016). Bonding of plywood. Research in Agriculture Engineering. 62, 4, 198-204.

[5] BROŽEK, M. (2016). Influence of the degreaser type in the bonder joint strength. Manufacturing Technology. $16,6,1248-1254$.

[6] BROŽEK, M. (2013). Optimization of Adhesive Layer Thickness at Metal Bonding Using Quick-Setting Adhesives. Manufacturing Technology. 13, 4, 419-423.

[7] CAGLE, Ch. V., LEE, H., NEVILLE, K. (1973). Handbook of adhesive bonding. New York, McGraw-Hill. 800.

[8] CHEN, C. M. (1995). Gluability of Kraft Lignin Copolymer Resins on Bonding Southern Pine Plywood. Holzforschung. 49, 153-157.

[9] CHENG, R. X., WANG, Q. W. (2011). The Influence of FRW-1 Fire Retardant Treatment on the Bonding of Plywood. Journal of Adhesion Science and Technology. 25, 1715-1724.

[10] EBNESAJJAD, S. (2008). Adhesives technology handbook. $2^{\text {nd }}$ Ed., Norwich, William Andrew. 363.

[11] ESTAN-CEREZO, G., MARTIN-MARTÍNEZ, J. M.: Thermal, viscoelastic and adhesion properties of EVA (ethylene-co-vinyl acetate) hot melts containing polypropylene waxes of different nature. Journal of Adhesion Science and Technology. 29, 9, 875-889.

[12] FAN, D. B., QIN, T. F., CHU, F. X. (2011). A new interior plywood adhesive based on oil-tea cake. Advanced Materials Research. 194-196, 2183-2186.

[13] GARCIA ESTEBAN, L., GARCIA FERNANDEZ, F., de PALACIOS, P. (2011). Prediction of Plywood Bonding Quality Using an Artificial Neural Network. Holzforschung. 65, 209-214.

[14] HE, G., FENG, M., DAI, C. (2012). Development of soy-based adhesives for the manufacture of wood composite products. Holzforschung. 66, 857-862.

[15] HUDEC, Z. (2012). Gas Metal Rapid Arc Welding Potential. Manufacturing Technology. 12, 13, 113-118.

[16] KOLAŘÍKOVÁ, M., KOLǍ̌ÍK, L., KOVANDA K., HRABINA, R. (2012). Welding of Normalized Heat Treated Steels S355NL Large Thicknesses by Method FCAW. Manufacturing Technology. 13, 2, 181-188. 
[17] KOMORNICKI, J., BOURREL, M., MARIN, G., BROGLY, M. Thermal and visco-elastic properties of EVAbased hot-melt adhesives: Relationship to peel behaviour. Journal of Adhesion Science and Technology. 6, 2, 293-305.

[18] NOVÁKOVÁ, A., BROŽEK, M. (2009). Bonding of non-metallic materials using thermoplastic adhesives. In.: Engineering for Rural Development. Jelgava, Latvia University of Agriculture, 261-264.

[19] OLIVARES, M., SELLERS, T. (1994). Resin-adhesive Formulations for Bonding Exterior-type Plywood Using Chilean Radiata Pine and 4 Hardwoods. Holzforschung. 48, 157-162.

[20] PARK, Y.-J., JOO, H.-S., KIM, H.-J., LEE, Y.-K.: Adhesion and rheological properties of EVA-based hot-melt adhesives. International Journal of Adhesion and Adhesives. 26, 8, 571-576.

[21] PIZZI, A., MITTAL, K. L. (2003). Handbook of adhesive technology. New York, Dekker, 1024.

[22] SELLERS, T. (1989). Diisocyanate Furfural Adhesive for Bonding Plywood. Forest Production Journal. 39, 5356.

[23] YANG, I., KUO, M., MYERS, D. J. (2006). Bond Quality of Soy-based Phenolic Adhesives in Southern Pine Plywood. Journal of the American oil chemistry society. 73, 231-237.

[24] ČSN EN 205 (66 8508) (2003). Lepidla - Lepidla na dřevo pro nekonstrukční aplikace - Stanovení pevnosti lepeného spoje ve smyku při tahovém namáhání (Adhesives - Wood adhesives for non-structural applications Determination of tensile shear strength of lap joints). ČNI.

[25] ČSN EN 636 (49 2419) (2013). Překližované desky - Požadavky (Plywood - Specification). ČNI.

[26] ČSN EN 1465 (66 8510) (2009). Lepidla - Stanovení pevnosti ve smyku při tahovém namáhání přeplátovaných lepených sestav (Adhesives - Determination of tensile lap-shear strength of bonded assemblies). ČNI. 